\title{
The Difference of Students' Ability on Mathematics Communication Through Numbered Heads Together Combined with Inductive Deductive Approach and Expository Method
}

\author{
Elisabeth Margareth Gultom \\ Post Graduate Program in Mathematics Education \\ Universitas Negeri Medan \\ Medan, Indonesia \\ Corresponding email: elisabethgultom.eg@gmail.com
}

\author{
Edi Syahputra \\ Post Graduate Program in Mathematics Education \\ Universitas Negeri Medan \\ Medan, Indonesia
}

\begin{abstract}
Numbered Heads Together is a coperative strategy that can improve student's mathematical communication ability. Mathematical communication is one of the mathematics' standard process that must be mastered by students. The purpose of this study is to determine whether students' mathematical communication ability through Numbered Heads Together combined with inductive and deductive approach is better than students' mathematical communication ability taught by expository method. This study is a quasi-experimental research using non-equivalent control group design. Two classes was taken as sample. The first class is called the experimental class and the second class is called the control class with the number of students in each class is 35 students. Measurement instrument using essay test. Based on data analysis, the average of students' mathematical communication ability increased by 1.457 for the experimental class and 0.832 for the control class. The result of $t$-test analysis shows that $t_{\text {count }}$ is greater than $t_{\text {table. }}$. This means that $H_{0}$ refused and $H_{a}$ accepted so students' mathematical communication ability who were taught by Numbered Heads Together combined inductive and deductive approach is better than students' mathematical communication.
\end{abstract}

Keywords-mathematical communication; deductive inductive approach; expository method

\section{INTRODUCTION}

One of the standard process that must be mastered by students is mathematical communication. NCTM (Ansari, 2009) suggests that:

Mathematics as a communication tool is the development of language and symbols to communicate mathematical ideas, so students can: (1) express and explain their thinking about mathematical ideas and its relationships; (2) formulate mathematical definitions and make generalizations gained through investigation; (4) reading mathematical discourse with comprehension, (5) explaining, proposing and expanding questions on mathematics that he has learned, and (6) appreciating the beauty and strength of mathematical notation, and his role in developing mathematical ideas [1].
Students' mathematical communication ability is really need to be developed, because through mathematical communication students can think mathematically both oral and writing.

The reality shows that the result of mathematics learning in Indonesia in the aspect of mathematical communication is still low. As revealed by Izzati (Prayitno, 2013), that the learning of mathematics for students is still not giving enough attention to the development of these capabilities [2]. The same thing was found by Kadir (Prayitno, 2013), that the students' mathematical communication in coastal areas is still low [3]. Qohar (Prayitno, 2013), said that students' mathematical communication skills (especially in non-urban areas) is still lacking, either verbal or written [4].

Written ommunication restricted on communication activities models Cai, Lane, and Jakabein, (Fachrurazi 2011) which includes:

1. Writing (writing), writing is a conscious activity to express and to reflect the contents of the mind that outlined in media, paper, and computer. Writing is useful tool because students earn mathematics experience as a creative activities.

2. Draw mathematics, students able to draw pictures, charts, graphs, and table completely as a result of the translation of a problem or idea. Drawing can also help children explain concepts or ideas, and make it easier for children to come up with breakthrough strategies.

3. Mathematical expression is a form of mathematical representation. Students able modeling mathematics then do calculation or got solutions [5].

On generally, communication that occurs in learning mathematics in the classroom only takes place in a linear manner, which means the communication only goes one way, with the teacher as the information giver, and the students as the recipient of the information. Lack of good communication with students is caused by the learning method that teachers used cannot enable students to communicate and to show their ideas. Teachers deliver materials directly and students not 
required to find their own understanding. This method of teaching is called the expository method.

One way that can be used to improve the ability of students' mathematical communication is to implement cooperative learning model, because one of the benefits of cooperative learning is the sharing process among the learn participants.

One type of cooperative learning is Numbered Heads Together. Numbered Heads Together (NHT) is type of cooperative learning that designed for affect students' interaction [6] Furthermore, Numbered Heads Together is combined with inductive and deductive approaches. The inductive approach is an approach that begins by presenting a number of specific circumstances then summed up into a fact, principle, or rule. While the deductive approach is the teaching approach that begins by presenting the rule, the general principle is followed by specific examples or application of the rule, the general principle into a special state.

The application of inductive and deductive approaches are in the phase of asking questions on learning syntax of Numbered Heads Together. Teachers will ask questions that will direct students in making conclusions and be able to apply the definition or concept that has been given. Implementing Numbered Heads Together with inductive and deductive approaches, make students either individually or in groups can be more active in the classroom and develop knowledge together.

The purpose of this study was to determine whether the students' mathematical communication skills who taught by Numbered Heads Together combined with inductive and deductive approaches are better than the ability of students' mathematical communication skill who taught by expository method.

\section{METHODOLOGY}

This study is a quasi-experimental research using nonequivalent control group design. Two classes was taken as sample. The first class is called the experimental class and the second class is called the control class. Before being given treatment, each class is given pretest first.

$\mathrm{T}_{1}=$ Pretest

$\mathrm{T}_{2}=$ Postest

$\mathrm{X}=$ Numbered Heads Together learning combined with inductive and deductive approaches.

$\mathrm{Y}=$ Expository learning.

For more details, please see this following table:

TABLE I. CONTROL GROUPS FORMED RANDOMLY AND GIVEN PRETES AND POSTES DESIGN
The population in this research is 324 students in Grade 8. Measurement instrument using essay test. Test given before and after learning. The analysis of the data is t-test.

Hypothesis to be tested is formulated as follows:

$$
\begin{aligned}
& H_{0}: \mu_{1} \leq \mu_{2} \\
& H_{a}: \mu_{1}>\mu_{2}
\end{aligned}
$$

$\mathrm{H}_{0}$ : Students' mathematical communication skills taught by Numbered Heads Together combined with inductive and deductive approaches is lower than or equal to a mathematical communication ability of students taught using expository method.

$\mathrm{H}_{\mathrm{a}}$ : Students' mathematical communication skills taught by Numbered Heads Together, combined with inductive and deductive approach is better than the written mathematical communication skills of students who are taught by expository method.

Testing criteria are: $\mathrm{H}_{0}$ accepted if $t<t_{1-\alpha}$, where $t_{1-\alpha}$ obtained from the distribution $t$ list with $d k=\left(n_{1}+n_{2}-2\right)$ and opportunities $1-\alpha$. For other t prices $H_{0}$ rejected.

\section{RESULT}

First, two classes ( experiment class and control class) are given pretest for knowing the initial of students' mathematical communication ability. In summary the pretest results of both groups are shown in Table II.

The table shows that the pretest average of experimental class is higher than the pretest average of control class. It is also seen that the maximum pretest value of students in the experimental class is lower than the maximum student pretest score in the control class.

At the end of the meeting, students are given postest. Postest given to determine the ability of the student mathematical communication after Numbered Heads Together with inductive deductive approach have been implemented in the experimental class and expository method in the control class. The summary the postest result of the two classes are shown in table III

TABLE II. DATA OF EXPERIMENT AND CONTROL ClASS

\begin{tabular}{|c|c|c|c|}
\hline No & Statistics & Experiment Class & Control Class \\
\hline 1 & $\mathrm{~N}$ & 35 & 35 \\
\hline 2 & Amount of Value & 44.56 & 32.32 \\
\hline 3 & Average & 1,273 & 0.923 \\
\hline 4 & Variance & 0.11 & 0.18 \\
\hline 5 & Standard deviation & 0.332 & 0.43 \\
\hline 6 & Maximum Value & 1.76 & 1.84 \\
\hline 7 & Minimum Value & 0.64 & 0 \\
\hline
\end{tabular}

\begin{tabular}{|l|l|l|l|}
\hline \multicolumn{1}{|c|}{ Group } & Pretest & Treatment & Postest \\
\hline Experiment & $\mathrm{T}_{1}$ & $\mathrm{X}$ & $\mathrm{T}_{2}$ \\
\hline Control & $\mathrm{T}_{1}$ & $\mathrm{Y}$ & $\mathrm{T}_{2}$ \\
\hline
\end{tabular}


TABLE III. POSTEST RESULT IN EXPERIMENT AND CONTROL CLASS

\begin{tabular}{|c|c|c|c|}
\hline No & Statistics & Experiment Class & Control Class \\
\hline 1 & $\mathrm{~N}$ & 35 & 35 \\
\hline 2 & Amount of Value & 83.1 & 61.12 \\
\hline 3 & Average & 2.73 & 1,746 \\
\hline 4 & Variance & 0.26 & 0.261 \\
\hline 5 & Standard deviation & 0.51 & 0.511 \\
\hline 6 & Maximum Value & 3.2 & 2.56 \\
\hline 7 & Minimum Value & 1.44 & 0.8 \\
\hline
\end{tabular}

From the table above it can be seen that the average postest in experimental class is higher than the average postest in control class. While the variance and standard deviation of the two classes are the same.

Then, Liliefors test is used to test the normality of the data. Data is distributed nolmal if $\mathrm{L}_{0}<\mathrm{L}_{\text {table }}$ with $\alpha=0.05$. the result of normality test is shown in table IV. The test of normality shows that $\mathrm{L}_{0}<\mathrm{L}_{\text {table }}$ in both class, so it can be concluded that the classes is normal distributed.

Furthermore, homogeneity test is taken. The result of homogeneity test is shown in table V. Table V shown that the variance of the experimental class is 0.235326 and the variance of control class is 0.151086 , which means the variance of the experimental class is greater than the control class variance, so from the calculation results obtained $\mathrm{F}_{\text {count }}=$ 1.5575 and $\mathrm{F}_{\text {table }}=1.776$ which mean $\mathrm{F}_{\text {count }}$ is lower than $\mathrm{F}_{\text {table }}$. So it can be concluded that both class come from homogeneous population.

Then hypothesis testing was taken. Testing hypothesis for mathematical communication skills of students performed on the data pretest and posttest through t test.

From calculation we obtained $t_{\text {count }}=2.66$ then $t_{\text {table }}=$ 1.66867 with level of significant $\alpha=0.05$. So, $t_{\text {count }}>t_{\text {table. Thus }}$ concluded that $\mathrm{Ha}$ is received or $\mathrm{H}_{0}$ rejected so concluded that mathematical communication skills of students taught by Numbered Heads Together combined with inductive and deductive approach is better than the written mathematical communication skills of students who are taught by expository method.

TABLE IV. NORMALITY TEST RESUlT IN BOTH ClASS

\begin{tabular}{|c|c|c|c|c|}
\hline NO & Class & $\mathrm{L}_{0}$ & $\mathrm{~L}_{\text {table }}$ & Information \\
\hline 1 & Experiment & 0.12839 & 0.149761 & Normal \\
\hline 2 & Control & 0.097543 & 0.149761 & Normal \\
\hline
\end{tabular}

TABLE V. HOMOGENEITY TEST RESUlT

\begin{tabular}{|c|c|c|c|c|}
\hline NO & Class & Variance & $\mathbf{F}_{\text {count }}$ & F $_{\text {table }}$ \\
\hline 1 & Experiment & 0.235326 & \multirow{2}{*}{1.5575} & \multirow{2}{*}{1.776} \\
\hline 2 & Control & 0.151086 & & \\
\hline
\end{tabular}

\section{DISCUSSION}

The differences between Numbered Heads Together with deductive inductive approach and learning by expository method is the existence of discussion activities with the group on the Numbered Heads Together with deductive inductive approach to discuss the questions given by the teacher.

Learning with Numbered Heads Together with deductive inductive approach makes students prefer to learn because students are encouraged to learn by interacting with their friends, so that students' enthusiasm in the learning process is high enough, and students are more actively learning, and the interaction between students with teachers is well established.

In the learning process, there are some weaknesses of the researcher:

1. When students are divided into discussion groups, the atmosphere in the class is not controlled (noisy) because students are less familiar with the way of learning Numbered Heads Together

2. It is difficult to make students more daring to express and communicate their opinions

3. It takes a lot of time to apply Numbered Heads Together with deductive inductive approach

4. The question of pretest and postes used is not yet a reliable measuring tool.

So for the next researcher must fix all the weakness in the next research so that can get better result

\section{CONCLUSION \& SUGGESTION}

\section{A. Conclusion}

Based on the results of research and discussion that has been described in the previous chapter, it can be summed up as follows: The ability mathematical communication students taught learning model Numbered Heads Together combined approach inductive and deductive more good rather than the mathematical communication ability of the students who were taught by the expository method on the functional material in class VIII of Negeri 1 Junior High School

\section{B. Suggestion}

As for suggestions that can be given from the results of this study, namely:

1) Teacher should study the cooperative learning model Numbered Heads Together to be applied in the study of mathematics because this model can help improve students' mathematical communication in writing.

2) School expected for more pay attention advantages and weakness from learning to use in teach mathematics in effort improve ability communication students.

3) Students should more confident and courageous to communicate his ideas and opinions and can better maintain order in the learning activities in the classroom.

4) For researchers who want to do the same study should prepare matter of mathematical communication skills test is more reliable in order to better disclosure of mathematical communication skills of students and do more thorough preparation and careful allocate time so students more active in the learning process teach and able improve ability communication be more good.

\section{REFERENCES}

[1] A. Bansu, Komunikasi, Matematik-Konsep dan Aplikasi. Banda Aceh: Sahabat Pena, 2009.

[2] A. Suharsimi, Dasar-dasar Evaluasi Pendidikan. Jakarta: Bumi Aksara, 2012. 
[3] Asmin, A. Mansyur, Pengukuran dan Penilaian Hasil Belajar dengan Analisis Klasik dan Modern. Medan: Larispa Indonesia, 2012.

[4] Fachrurazi, "Penerapan Pembelajaran Berbasis Masalah Untuk Meningkatkan Kemampuan Berpikir Kritis dan Komunikasi Matematis Siswa Sekolah Dasar", vol 1, pp. 76 - 88.

[5] Isjoni, Cooperative Learning-Efektivitas Pembelajaran Kelompok. Bandung: Alfabeta, 2011.

[6] Istarani, 58 Model Pembelajaran Inovatif, Medan: Media Persada, 2012.

[7] I. Nur, "Komunikasi matematik dan pendidikan matematika realistik", [Prosiding Seminar Nasional Matematika dan Pendidikan Matematika, pp. 721-725]

[8] P. Sudi, "Komunikasi matematis siswa smp dalam menyelesaikan soal matematika berjenjang ditinjau dari perbedaan gender", November 2013
[Seminar Nasional Matematika dan Pendidikan Matematika.Pendidikan Matematika FMIPA UNY]

[9] Q, Abdul. "Pengembangan instrumen komunikasi matematis untuk siswa smp", 2011 [Lomba dan Seminar Matematika XIX :46-47]

[10] R. Yatim, Paradigma Baru Pembelajaran. Jakarta: Prenada Media Grup, 2010.

[11] S. Sagala, Konsep dan Makna Pembelajaran, Bandung: Alfabeta, 2009

[12] S. Wina, Strategi Pembelajaran Berorientasi Standar Proses Pendidikan, Bandung: Prenada Media Grup, 2011

[13] S, Nana. Metoda Statistika, Bandung: Tarsito, 2002

[14] Trianto, Mendesain Model Pembelajaran Inovatif-Progresif. Jakarta: Kencana, 2010 